\title{
The Biological Purification Project Practice of the Sewage Treatment Station's Odor
}

\author{
Feng $\mathrm{Yu}$ \\ Shenyang City Environmental Protection Bureau \\ Shenyang Environmental Protection Engineering \\ Design Institute \\ Shenyang, China \\ zjpsdwf@163.com
}

Hongqi Zhu

Shenyang City Environmental Protection Bureau Shenyang Environmental Protection Engineering

Design Institute

Shenyang, China

764285929@qq.com

\author{
Yanjun Yin \\ Shenyang City Environmental Protection Bureau \\ Shenyang Environmental Protection Engineering \\ Design Institute \\ Shenyang, China \\ 472225262@qq.com
}

\begin{abstract}
Secondary pollution, caused by the stench gas from the sewage treatment plant (station), has become one of the key environmental petition complaint. In this paper, the impact of malodorous gases Harbin Brewery (Shenyang) Co., sewage treatment station for residents, set design and construction of washing humidification, chemistry and physical adsorption and biodegradation as one of the malodorous gas purification facilities, effective solution to the problem of foul-smelling gas pollution nuisance.
\end{abstract}

Keywords- pollution;Gas purification;Deodorant; Contro; effective solution

\section{INTRODUCTION}

Anheuser-Busch InBev (Shenyang) Co., Ltd. acquired the original beer Spartak Lu Shenyang Brewery Co. in 2003. After expanding, it is gradually developed into the modern enterprise annual outputting 100,000 tons of beer production. With the process of urbanization, east and south of the company gradually built residential areas. But the new residential is only 30 meters away from sewage treatment plant and the civil repeatedly complained that the company's sewage treatment plant odor pollution nuisance problems to the environmental protection department.

Shenyang Environmental Protection Engineering Design and Research Institute of the items bear the stench of sewage treatment station to collect gas purification project design. The total investment of biological deodorization is $\$ 380,000$, dealing with the scale of $2600 \mathrm{~m}^{3} / \mathrm{h}$. The project technology, access to a national invention patents, Liaoning Province, a scientific and technological achievements ${ }^{[1-5]}$.

\section{DEODORIZATION PROCESS ENGINEERING TO DETERMINE}

\section{A. Determine of the source stench}

The main treatment facility of sewage station from InBev (Shenyang) Beer Co. has regulation pool, acidification tank, anaerobic tower, aerobic biochemical pool, and secondary sedimentation tank, sludge dewatering, etc. And the main malodorous gases to affect the lives of residents come from between the coarse grid, between fine grid, between acidification tank, IC reaction between the tank and sludge dewatering, which thickness grill well, anaerobic acidification tank, anaerobic digestion drainage, sludge thickening, sludge dewatering is the main production processes and sewage node generates odor. Malodorous gases mainly composed of $\mathrm{H}_{2} \mathrm{~S}, \mathrm{NH}_{3}, \mathrm{PH}_{3}$, methyl merchantman, diethyl sulfide, etc., among $\mathrm{H}_{2} \mathrm{~S}$, $\mathrm{NH}_{3}$ content more.

\section{B. Process Selection of odorous gas purification}

Wastewater treatment, sludge treatment and garbage disposal facilities, is an important source of malodorous gases. In sewage treatment, different treatment facilities and process will produce a variety of malodorous gases. Sewage treatment plant influent pumping station odor of hydrogen sulfide produced mainly; odor early settling tank sludge produced in the process of anaerobic digestion to hydrogen sulfide and other sulfur-based gases; sludge digestion process will stabilize produce ammonia and other volatile substances. Garbage composting process will produce ammonia, amines, sulfur compounds, fatty acids, and aromatic and diethyl sulfur odor. Aerobic digestion and sludge drying process may produce a small amount of hydrogen sulfide, but the main thiol and diethyl sulfide gases.

Odor-causing substance is mainly composed of carbon, nitrogen and sulfur elements in the sewage treatment process. Only a few of the odor substance is an inorganic compound, for example: ammonia $\left(\mathrm{NH}_{3}\right)$, phosphate $\left(\mathrm{PH}_{3}\right)$ and hydrogen sulfide $\left(\mathrm{H}_{2} \mathrm{~S}\right)$; most odor substances are organic compounds, such as: low molecular weight fatty acids, amines, baldheads, ketenes, ethers, halogenated hydrocarbons and aliphatic, aromatic, heterocyclic nitrogen or sulfur compounds. Notably: these substances 
with active groups, prone to chemical reactions, particularly oxidation. When the reactive group is oxidized, odor disappears; biological deodorization process is based on this principle.

Harbin Brewery (Shenyang) Co., Ltd. The main treatment process for regulating sewage station, acidification, anaerobic, aerobic, look at the whole process from the generation source emissions are mainly between coarse grid, between the fine grid, acidification tank, IC between the reaction tank and sludge dewatering, the main material of these odor is $\mathrm{H}_{2} \mathrm{~S}, \mathrm{NH}_{3}, \mathrm{PH}_{3}$, methyl merchantman, diethyl sulfide, of which the $\mathrm{H}_{2} \mathrm{~S}, \mathrm{NH}_{3}$ more content.

The process of sewage treatment in our hospital in the past, especially the beer sewage treatment process, repeated application of chemical treatment process to absorb malodorous gas purification. It is advantages that chemical absorption purification process has facilities covering a small area, handling fast, and high purification efficiency, at the same time, there is a chemical treatment process to absorb the high processing costs, unstable effect, easy to cause pollution problems again. Therefore, this project malodorous gas purification technology for existing screening was compared. (TABLE I ).

TABLE I. COMPARISON OF THE MAIN DEODORANT TECHNOLOGY

\begin{tabular}{|c|c|c|c|c|c|}
\hline $\begin{array}{l}\text { Techn } \\
\text { ical } \\
\text { indica } \\
\text { torsns }\end{array}$ & $\begin{array}{c}\text { Biofiltr } \\
\text { ation }\end{array}$ & $\begin{array}{c}\text { Biologi } \\
\text { cal } \\
\text { sprays }\end{array}$ & $\begin{array}{c}\text { Chemi } \\
\text { cal } \\
\text { absorp } \\
\text { tion }\end{array}$ & $\begin{array}{c}\text { Alkali } \\
\text { washin } \\
g \\
\text { absorp } \\
\text { tion }\end{array}$ & $\begin{array}{c}\text { Catalyt } \\
\text { ic } \\
\text { inciner } \\
\text { ation }\end{array}$ \\
\hline $\begin{array}{l}\text { Purific } \\
\text { ation } \\
\text { load } \\
\text { Proces } \\
\text { sing } \\
\text { capacit } \\
\text { y }\end{array}$ & higher & high & middle & middle & high \\
\hline $\begin{array}{l}\text { Reside } \\
\text { nce } \\
\text { time }\end{array}$ & high & high & low & low & low \\
\hline $\begin{array}{l}\text { Facilit } \\
\text { ies } \\
\text { resista } \\
\text { nce }\end{array}$ & lower & lower & low & low & low \\
\hline $\begin{array}{l}\text { Secon } \\
\text { dary } \\
\text { polluti } \\
\text { on }\end{array}$ & none & none & exist & exist & exist \\
\hline $\begin{array}{l}\text { Operat } \\
\text { ing } \\
\text { costs } \\
\text { Projec }\end{array}$ & low & high & high & high & high \\
\hline $\begin{array}{l}\mathrm{t} \\
\text { invest } \\
\text { ment }\end{array}$ & low & higher & low & lower & high \\
\hline
\end{tabular}

After comparing the technical and economic analysis, taking into account the site conditions of Anheuser-Busch InBev (Shenyang) Co. beer stench of sewage station decontamination, determine the use of the biological filter bed deodorization processes. Engineering practice shows that compared with other methods of physical and chemical odors, biological deodorization process has advantages of less investment, stable affections and low operating cost, which avoided secondary pollution odor treatment.

\section{PROCESS AND SySTEM DESIGN}

\section{A. Biological malodorous gas collection system design}

Gas collection system, shown in Figure 1, The odor source through pipelines for centralized odor by induced draft fan introducing humidifying tower, ensure the odor of the humidity saturated, humidification inside double stage packing, outside the tower set 1 sets of explosion-proof spray pump to maintain humidification water pressure, ensure the atomizing effect of spray water, gas and liquid in the packing above the reverse flow full contact, relative the humidified gas humidity reached $80 \%$ in order to achieve the appropriate living conditions microbial filler inside the tower, the humidity odor ${ }^{[6-10]}$.

After humidifying gas again into biological deodorization filter bed, biological deodorization filter bed according to the different proportion of stacked biological filler, through the air distribution plate to make the role of odor molecules are fully and fixed on the biological species to inert packing surface, inert exhaust gas into the biological packed layer of membrane hanging over the later part of the gas into the liquid phase, a part of the gas inert filler Jane biological surface membrane into microbial capture, absorption, adsorption and degradation, microbial deodorization filter bed to cell individual small, specific surface area, strong adsorption, metabolism and various types of odorous substances, can be absorbed into the adsorption free of toxic $\mathrm{CO}_{2}, \mathrm{H}_{2} \mathrm{O}, \mathrm{H}_{2} \mathrm{SO}_{4}, \mathrm{HNO}_{3}$ simple inorganic compounds.

Cell body and the room each odor source has stench suction pipe, and the pipe material used plexiglass tube, controlling the wind speed between 8 to $10 \mathrm{~m} / \mathrm{s}$, the coarse grid, between fine grid, sludge dewatering room odor inhalation pipeline is $\mathrm{DN} 150$, in order to make the odor between the grille inhalant evenly over the coarse grid and fine grid and sludge dewatering machines have stainless steel collection hood, the inside of the hood has set DN80, $150 \mathrm{~mm}$ spacing odor coil and in the coil suction hole opened above $25 \times 70$ pitch 200. Acidification tank, anaerobic tower and features the same odor DN150 suction pipe. There are the wind valves above suction pipe each odor source, common pooling to DN300 odor mains road to the induced draft fan. Induced draft fan with explosionproof glass blower motors, flow $\mathrm{Q}=4600 \mathrm{~m} 3 / \mathrm{h}$, the pressure $\mathrm{P}=3 \mathrm{Kpa}$, power $\mathrm{N}=5.5 \mathrm{kw}$.

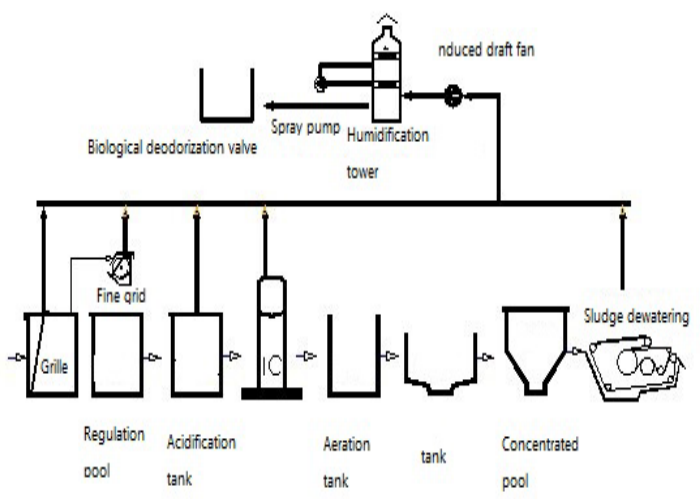

Figure 1. Flow Chart 


\section{B. Spray washing absorber design}

The method used in this project to keep biological filter bed moisture, which directly humidified the influx air to achieve adequate humidity. Spray washing absorber designed individually, shown in Figure 2,humidification tower dimensions size is $\Phi 2.4 \mathrm{~m} \times 2.0 \mathrm{~m}$, equipping with dual-stage fillers, In order to ensure the humidification water's pressure in tower, peripherals with two chemical preservative spray pumps are explosion-proof motors, flow $\mathrm{Q}=11 \mathrm{~m} 3 / \mathrm{h}$, pressure $\mathrm{H}=20 \mathrm{~m}$, power $\mathrm{N}=2.2 \mathrm{kw}$.

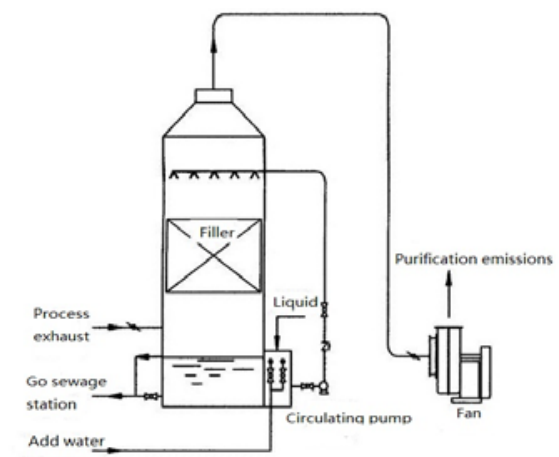

Figure 2. spray washing absorption tower design

\section{Biological deodorization pool design}

Biological deodorizing filter biological purification's effect depends on the quality the filler and the suitability of bio .To ensure the stability and reliability of biological deodorization, the project biological deodorization filter tank particularly design is that chemical lime neutralization and plastics physical adsorption, Bio-filler' purify all focus designed the compound biological deodorizing device, discharge standards gas through pipes into the aeration blowers to recycling. Biological deodorization tank designed that brick of bottom and the wall designed with $2 \mathrm{~m}$ FRP to corrosion seepage, reserved a set of drainage and leakage for filter cleaning sewage. Laying the bottom guide wall mounted gas distribution pipelines were designed and the branch, (pitch $500 \mathrm{~mm}$ ) height $500 \mathrm{~mm}$, to ensure uniform distribution through odor. PVC perforated plate supporting gas distribution, $30 \%$ area of the hole, followed by a single layer on top of the perforated plate packing, mixed packing, And mixed filler stacking requirements are divided into three layers, between each layer thin breathable mesh isolation, in order to avoid confounding influence of different fillers turbostratic purifying effect., shown in Figure 2.

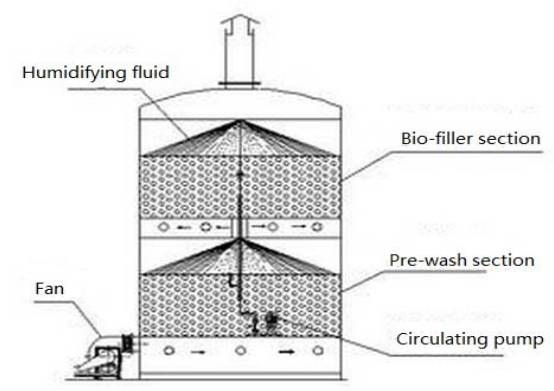

- Biological filter selection

It is essential core technologies to biological deodorization packing, it should be a high porosity, fast microbial inoculation, easily grow, balanced nutrition, absorbent, easy to obtain, low price and easy conservation updates and other features. After preliminary study of small-scale experiments, the mixed packing is the new biomass particle filter department of our hospital's own research and invent; the main component of straw, sawdust, corn cob, mixed sludge processed into particles. Biological particle filter size in $20 \mathrm{~mm}-50 \mathrm{~mm}$, the porosity of $0.78 \mathrm{~m} 3$ $/ \mathrm{m}^{3}$, the accumulation coefficient of approximately 55800 $/ \mathrm{m}^{3}$.

Practice has proved that the use in the bio-filter purification devices has low costs of investment and operating, and less filler loss, after five years of operation carried on a small amount of additional, deodorizing effect remains stable. Single packing: diameter $50 \mathrm{~mm}$, packing height $300 \mathrm{~mm}$; mixed filler: diameter $20 \mathrm{~mm}-50 \mathrm{~mm}$, packing height $1300 \mathrm{~mm}$.

- Contact reaction time

The residence time of the odor in the biological filter bed directly affects treatment effects. If the residence time is too short, it was ruled out of the bed because the odor pollution ingredient has not been fully absorbed by the biofilm, which lead the maximum amount of odor not to be degraded transformed. Otherwise, it will make the bed too large, while also increasing the system resistance, the equipment investment and the operation costs; therefore, it is the key to the success of biological deodorization. Referring to the small pre-test results and learning from the experience of the relevant technology, biological filter bed reactor residence time designed for $30 \mathrm{~s}$.

- Temperature control

Anheuser-busch inbev beer (shenyang) co., LTD mixed waste heat steam and biochemical reaction gas to deal with odor in the sewage station grille hole degree, and the temperature fluctuated between $20{ }^{\circ} \mathrm{C}$ to $55{ }^{\circ} \mathrm{C}$ from $20{ }^{\circ} \mathrm{C}$ to $55{ }^{\circ} \mathrm{C}$. The process of Biological deodorization device operated, it is found that the best temperature for biological filter bed is from 25 to $37{ }^{\circ} \mathrm{C}$, so we don't consider the control of the temperature.

- Humidity control

Odor pollutants should be firstly absorbed by the liquid phase and should be oxidized and degraded by microbial, so demand odor material maintain appropriate humidity in a 40-70\%. Low humidity causes dry fillers easily, Malodorous ingredients into the liquid difficultly reduces bed biological activity, directly affecting deodorization efficiency. If biological filter humidity is too high, and because of gas through the resistance increasing, affect the transfer efficiency, and even produce anaerobic reaction, which caused the failure of deodorization project.

- $\quad$ PH control

The project's the main pollution for the metabolism of organism in biological filter bed is closely related to the $\mathrm{pH}$. Many microorganisms to grow only in certain $\mathrm{pH}$ scope, the optimal $\mathrm{pH}$ and the vast majority of microbial growth in neutral range. In order to maintain a stable $\mathrm{pH}$ range the project through to the biological filter bed adding limestone.

Figure 3. biological deodorization pool design 


\section{THE SYSTEM RUNNING EFFECT}

Harbin Beer (Shenyang) station is located in the residential area to determine the town planning Co., sewage treatment, commercial traffic residents mixed area, cultural area, general industrial area and rural area as the air quality of the environment two area, should carry out the two national ambient air quality standards; field emission concentration plant malodorous gas after treatment must meet "urban sewage treatment plant pollutant discharge standard" GB18918-2002, GB14554 emission standards for odor pollutants.

After system put into operation 3 months ,all control project reached the standard - shown in TABLE II, and successfully passed the testing and acceptance of local environmental protection department, nearby residents did not complainer the issue again.

TABLE II. CONTROL THE PROJECT LIST

\begin{tabular}{|c|c|c|c|c|}
\hline \multirow[t]{2}{*}{$\begin{array}{c}\text { serial } \\
\text { number }\end{array}$} & \multirow[t]{2}{*}{ controlling item } & \multirow[t]{2}{*}{ unit } & \multicolumn{2}{|c|}{ data } \\
\hline & & & standard & $\begin{array}{c}\text { measured } \\
\text { value }\end{array}$ \\
\hline 1 & $\mathrm{~N}_{3} \mathrm{H}$ & $\mathrm{mg} / \mathrm{m}^{3}$ & 1.5 & 0.65 \\
\hline 2 & $\begin{array}{c}\mathrm{C}_{3} \mathrm{H}_{9} \mathrm{~N} \\
\text { (Trimethylamine) }\end{array}$ & $\mathrm{mg} / \mathrm{m}^{3}$ & 0.08 & - \\
\hline 3 & $\begin{array}{l}\mathrm{H}_{2} \mathrm{~S} \text { (hydrogen } \\
\text { sulfide) }\end{array}$ & $\mathrm{mg} / \mathrm{m}^{3}$ & 0.06 & 0.032 \\
\hline 4 & $\begin{array}{c}\mathrm{CH}_{4} \mathrm{~S} \text { (methyl } \\
\text { mercaptan) }\end{array}$ & $\mathrm{mg} / \mathrm{m}^{3}$ & 0.007 & - \\
\hline 5 & $\begin{array}{l}\mathrm{C}_{2} \mathrm{H}_{6} \mathrm{~S} \text { (dimethl } \\
\text { sulfide) }\end{array}$ & $\mathrm{mg} / \mathrm{m}^{3}$ & 0.07 & - \\
\hline 6 & $\begin{array}{c}\mathrm{C}_{2} \mathrm{H}_{6} \mathrm{~S}_{2} \text { (methyl } \\
\text { disulfide) }\end{array}$ & $\mathrm{mg} / \mathrm{m}^{3}$ & 0.06 & - \\
\hline 7 & $\begin{array}{c}\mathrm{CS}_{2} \text { (carbon } \\
\text { disulfide) }\end{array}$ & $\mathrm{mg} / \mathrm{m}^{3}$ & 3.0 & - \\
\hline 8 & $\mathrm{C}_{8} \mathrm{H}_{8}($ styrene $)$ & $\mathrm{mg} / \mathrm{m}^{3}$ & 5.0 & - \\
\hline 9 & Odor concentration & dimensionless & 20 & 15 \\
\hline
\end{tabular}

\section{REFERENCES}

[1] Leizhu Shi. Odor Pollution Measurement and Control Technology [M], Chemical Industry Press, 2004

[2] Xiaojun Xu,Lei Gong,Hong Yang. Malodorous gases biological purification Theory and Technology $[\mathrm{M}]$, Chemical Industry Press, 2005

[3] Deming Fang,Bingbing Chen. Air pollution control technology and equipment, Chemical Industry Press, 2005

[4] Jianguang $\mathrm{Wu}, Y a m i n$ Sun,Zhibin $\mathrm{Lu}$. Urban sewage treatment plant odor pollution control technology [J], Hefei University of Science News（Natural Sciences）, 2001 : 998-1001

[5] Jia Zhu,Wenyi Dong,Hong Du. Sewage stench control technology progress [M], Water Treatment Technology, $2006: 5-8$

[6] Chou M., Lu S., Treatment of 1, 3-Butadiene in an Air Stream by a Biotrickling Filter and a Biofilter, J. Air \& Waste Manage. Assoc. 1998, 48(8):711-720

[7] Fan L. S, Leyva-Ranos T. R., Wisdecarver, K.Zehner B. J., Diffusion of Phenol Through a Biofilm Grown on Activated Carbon Particles in a Draft-Tube Three-Phase Fluidized-Bed Bioreactor. Biotechnol. \& Bioengin, 1990, 35 (3): 279-286

[8] Claire, Shang Wei, Kuang shadow. Sewage treatment plant odor condition analysis and evaluation of [J]. China water supply and drainage, 2002,18 (2), 41 42

[9] Li Guowen, Hu Hong Ying, Hao Jiming, et al. The biological degradation of chlorobenzene waste gas washing tower performance research of [J] North Engineering, 2003,31 (5): 51 5

[10] Lu Yinghong. North of Shenyang city sewage treatment plant sludge and odor pollution situation and Prevention Countermeasures of $[\mathrm{J}]$ environmental protection science, 1999, 25 (3): $13-15$. 